\title{
M.STER
}

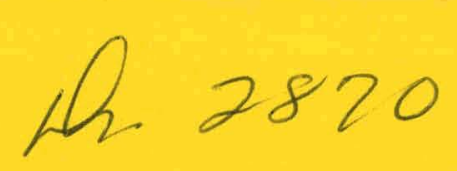

DOE/NASA CONTRACTOR

DOE/NASA CR-161236 REPORT

\section{INDOOR TEST FOR THERMAL PERFORMANCE EVALUATION OF SEVEN ELCAM FIN-TUBE SOLAR COLLECTOR CONFIGURATIONS}

\section{Prepared by}

Wyle Laboratories

Solar Energy Systems Division

Huntsville, Alabama 35805

Under subcontract with IBM Corp, Federal Systems Division,Huntsville, AL 35805

Contract NAS8-32036

National Aeronautics and Space Administration

George C. Marshall Space Flight Center, Alabama 35812

For the U. S. Department of Energy

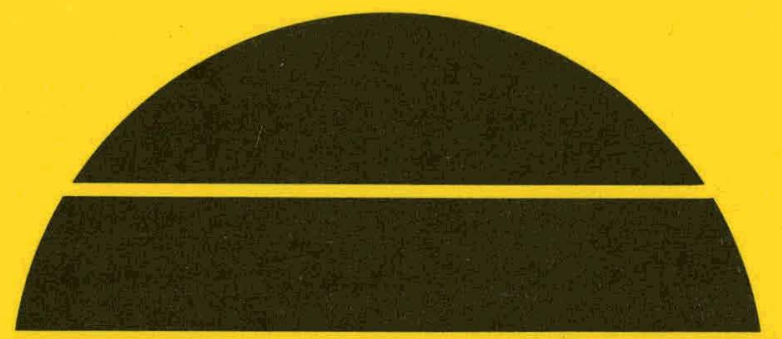

\section{U.S. Department of Energy}




\section{DISCLAIMER}

This report was prepared as an account of work sponsored by an agency of the United States Government. Neither the United States Government nor any agency Thereof, nor any of their employees, makes any warranty, express or implied, or assumes any legal liability or responsibility for the accuracy, completeness, or usefulness of any information, apparatus, product, or process disclosed, or represents that its use would not infringe privately owned rights. Reference herein to any specific commercial product, process, or service by trade name, trademark, manufacturer, or otherwise does not necessarily constitute or imply its endorsement, recommendation, or favoring by the United States Government or any agency thereof. The views and opinions of authors expressed herein do not necessarily state or reflect those of the United States Government or any agency thereof. 


\section{DISCLAIMER}

Portions of this document may be illegible in electronic image products. Images are produced from the best available original document. 
NOTICE

This report was prepared to document work sponsored by the United States Govermment. Nelther the United States nor its agents the United States Departmant of Energy, the United States National Aeronautics and Space Adminiatration, nor any federsl employees, nor any of thef: contractors, sutcortractors or their employee,, make any warranty, express or lifflitd, or assume any legal 11ability or responsibllity for the cccuracy, completeness, or usefulness of any information, apparatus, product or process disclosed, or represent that its use would not Infringe privately owned rights. 


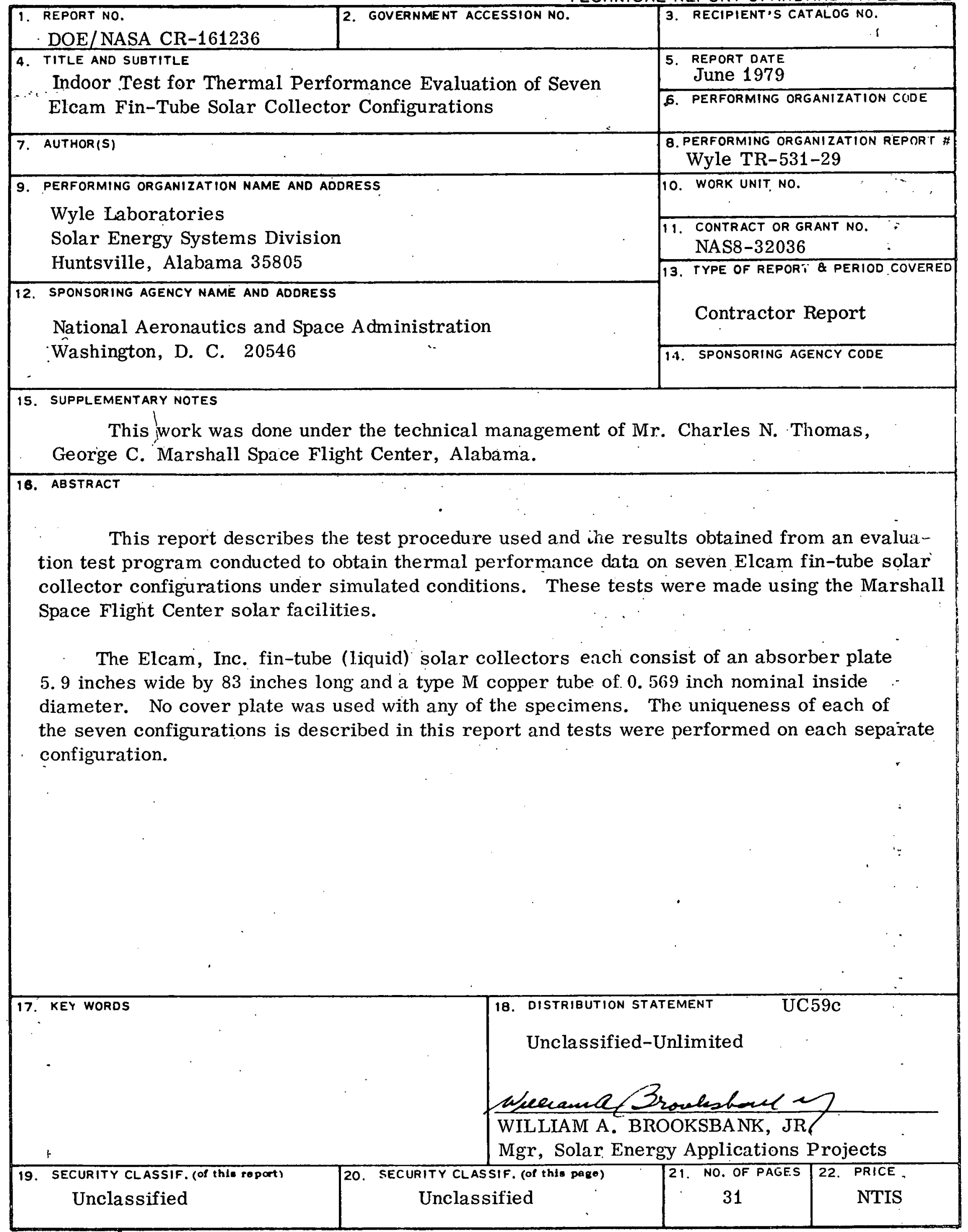


THIS PAGE

\section{WAS INTENTIONALLY LEFT BLANK}


TABLE OF CONTFNTS

Page No.

SUMMARY

PURPOSE

REFERENCES

MANUFACTURER

3.1 Description of Test Specimen

TEST CONDITIONS AND TEST EQUIPMENT

4.1 Ambient Conditions

4.2 Instrumentation and Equipment

5.2 Test Procedure

5.3 Results

TABLE II Thermal Performance Test Data for Elcam Configuration \#2

TABLE III Thermal Pexformance Test Data for Elcam Configuration \#3

TABLE IV Thermal Performance Test Data for Elcam Configuration \$4

TABLE V

Thermal Performance Test Data for Elcam Configuration \#5

TABLE VI

Thermal Performance Test Data for Elcam Configuration \#6

TABLE VII Thermal Performance Test Data for Elcam Configuration $\$ 7$

TABLE VIII Ranking of the Seven Elcam Configurations Based on Overall Performance 
Page No.

Figure 1. Schematic of Test specinen and Supporting Apparatus

Figure 2. Basic Design for Elcam Configurations $\# 1$, \#2, \#3, añ̄ \#6

Figure 3. Basic Design for Elcam Configurations \#4 and \#7

Figure 4. Basic Design for Elcam Configuration \#5

Figure 5. Indoor Thermal Performance Test Results for Elcam Configuration \#I

Figure 6. Indoor Thermal Performanse Test Results for Elcam Configuration \#2

Figure 7. Indoor Thermal Performance Test Results for Elcam Configuration \#3

Figure 8. Indoor Thermal Performance Test Results for Elcam Coriziguratisn ":

Figure 9: Indoor Thermal Performance rest Results for Elcam Configuration \#5

Figure 10. Indoor Thermal. Performance Test Results for Elcam Configuration \#6

Figure 11. Indoor Thermal Performance Test Results

for Elcam Configuration \#7

Figure 12. Summary of Thermal Performance Results for All Seven Elcam Configurations 
SUMMARY

Thermal performance tests have been conducted on seven Elcam solar collector absorber plates. Three basic fin-tube designs, as shown in Figures 2 through 4, were evaluated, with the addition of thermal compound (Eccotherm TC-4) and turbulating deformations as parameters. The tests were conducted indoors utilizing the Marshall Space Flight Center Solar Simulator to eliminate large excursions in the available solar flux, wind, and ambient temperature. The absorber plates were also removed from the SUNSPOT \#3200 collector enclosure and tested individually, using the apparatus shown in Figure 1. The individual testing eliminated the tedious effort required to balance the flow rate.

Results of the tests are shown graphically in Figures 5 through 12. Tables I through VII contain supporting test data recorded during the tests. Table VIII provides a summary of the test results, indicating efficiency as a function of inlet temperature. 


\section{$1.0 \quad$ PURPOSE}

The purpose of this report is to present the test procedures used and the test results obtained in conducting an evaluation test program to determine the thermal performance of seven Elcam fin-tube solar collector absorber plate configurations. The tests were conducted utilizing the Marshall Space Flight Center Solar Simulator in accordance with the test procedures of Reference 2.1 and the test requirements of Reference 2.2.

$2.0 \quad$ REFERENCES

$2.1 \quad$ MTCP-FA-SHAC -400

Frocedure for Operation of the MSFC Solar Simulator Facility

2.2 ASHRAE $-93-77$

Methods of Testing to Determine the Thermal Performance of Solar Collectors

MANUFACTURER

Elcam, Inc.

Santa Barbara, California

3.1 Description of Test Specimen

The test articles each consist of an absorber plate 5.9 inches wide by 83 inches long and a type $M$ copper tube of 0.569 inch nominal inside diameter. No cover plate was used with any of the specimens. The uniqueness of each of the seven configurations is described below:

(1) The base fin shown in Figure 2. Extruded aluminum $f$ in 0.0625 inch thick, coated with a black siliconized polyester baked or air dried enamel, snaps around the tube.

(2) Same as (1) except Eccotherm TC-4, heat transfer compound, was applied prior to snapping the tube into the fin.

(3) Same as (1) except a black chrome selective coating was used.

(4) The wraparound $\mathrm{E}$ in shown in Figure 3. A copper sheet 0.024 inch thick was secured around the tube. Eccotherm TC-4 wis used between the fin and the tube. Coating same as (1). Pop rivets fastened the $\mathrm{f}$ in around the tube. 
3.1 Description of Test specimen (Continued)

(5) The integrai tube-fin shown in Figure 4. A copper sheet $0: 024$ inch thick was used for fin and tube. The seam was silver soldered. The coating was the same as (1).

(6) Same as (2) except turbulating deformations were added to the tube. An approximate sine wave of $0.25 \mathrm{D}$ amplitude and a period of $2 \mathrm{D}$, where $\mathrm{D}$ is the inside tube diameter. The frequency was $10 \mathrm{D}$.

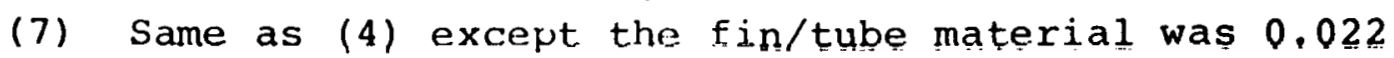
inch thick aluminum shect. 
4.0 TEST CONDITIONS AND TEST EQUIPMENT

4.1 Ambient Conditions

All tests were performed at ambient conditions existing in Building 4619.at. the time of the tests.

4.2

Instrumentation and Equipment

All test equipment and instrumentation used in the performance of this test program comply with the requirements of MSFC MMI 5300.4C, Metrology and Calibration. A standard test setup is depicted in Reference 2.1.

Apparatus

Liquid Loop

Flowmeter

Temperature Sensor

Pyranometer

Strip Chart Recorder

Solar Simulator
Manufacturer/Model

MSFC Supplied

Foxboro/1/2 - 2 81T361

Analog Devices

Eppley - PSP

Mosley 680

MSFC Supplied
Range/Accuracy

$0.1-1.12$ GPM

$0.1-1.2$ GPM \pm 18

$0-500^{\circ} \mathrm{F} \pm 0.1^{\circ} \mathrm{F}$

$0-800 \mathrm{BTU} / \mathrm{Ft}^{2} \cdot \mathrm{Hr}$ (Class 1)

$5-500 \mathrm{MV} \pm 28$

See Reference 2.1 
The requirements of this test were to obtain performance data at inlet temperatures of ambient, ambient $+50^{\circ} \mathrm{F}$, and ambient $+100^{\circ} \mathrm{F}$, with a controlled liquid flow rate of $0.15 \mathrm{GPM}$ at solar flux levels of $300 \mathrm{BTU} / \mathrm{Hr}-\mathrm{Ft}^{2}$. The tests were repeated for a liquid flow rate of $0.30 \mathrm{GPM}$. The following data were recorded for the tests:

(1) Ambient temperature

$\left({ }^{\circ} \mathrm{F}\right)$

(2). Solar flux (BTU/Hr-Ft ${ }^{2}$ )

(3) Liquida flow rate (GPM)

(4) Wind Speed (MPH)

(5) Liquid Inlet Temperature $\left({ }^{\circ} \mathrm{F}\right)$

(6) Liquid Outlet Temperature $\left({ }^{\circ} \mathrm{F}\right)$

Liquid temperature measurements were taken from locations identified in Figure 1.

Test Procedure

(1) Prepare test setup as shown in Figure' 1; mounting specimen fixture on the test table at an angle of $45^{\circ}$ with respect to the floor and connect instrumentation leads to the data acquisition system.

(2) Assure that the simulator lamp array is adjusted to a $45^{\circ}$ angle with respect to the floor.

(3) Align the test table so that the test specimen's vertical centerline coincides with the vertical centerline of the lamp array and the distance from the test specimen to the plane of the lamp array lens is 9 feet.

(4) Assure that the data acquisition system is operational.

(5) Power up the simulator and establish a solar flux level of $300 \mathrm{BTU} / \mathrm{Hr}-\mathrm{Ft}^{2}$.

(6) Assure that the wind speed is $0 \mathrm{mph}$.

(7) Establish the required liquid flow rate of 0.15 GPM.

(8) Determine the ambient temperature. 
5.2 Test Procedure

(9) Adjust the liquid inlet temperature to equal the ambient air temperature.

(10) After steady state conditions have been established, record data at one minute intervals for five minutes.

(11) Repeat steps 8, 9, and 10, changing the liquid inlet temperature as stated in paragraph 5.1, until all of the specified data has been obtained.

(12) Repeat steps 8 through 11 with a liquid flow rate of $0.30 \mathrm{GPM}$.

(13) Upon completion of testing, power down the simulator and liquid loop.

5.3 Results

The results obtained during the testing of the seven configurations are shown graphically in Figures 5 through 11 , respectively. A summary of the graphic results is shown in Figure 12. The supporting data obtained during the tests is shown in Tables I through VII, with a sumary shown in Table VIII. 
6.0 ANALYSIS OF RESULTS

6.1 : Thermal Performance Test

The analysis of data contained in this report is in accordance with the National Bureau of Standards recommended approach. This approach is outlined below.

The efficiency of a collector is stated as:

$\eta=\frac{q_{u} / A}{I}=\frac{\dot{m} C_{t f}\left(t_{f, e}-t_{f, i}\right)}{I}$.

where:

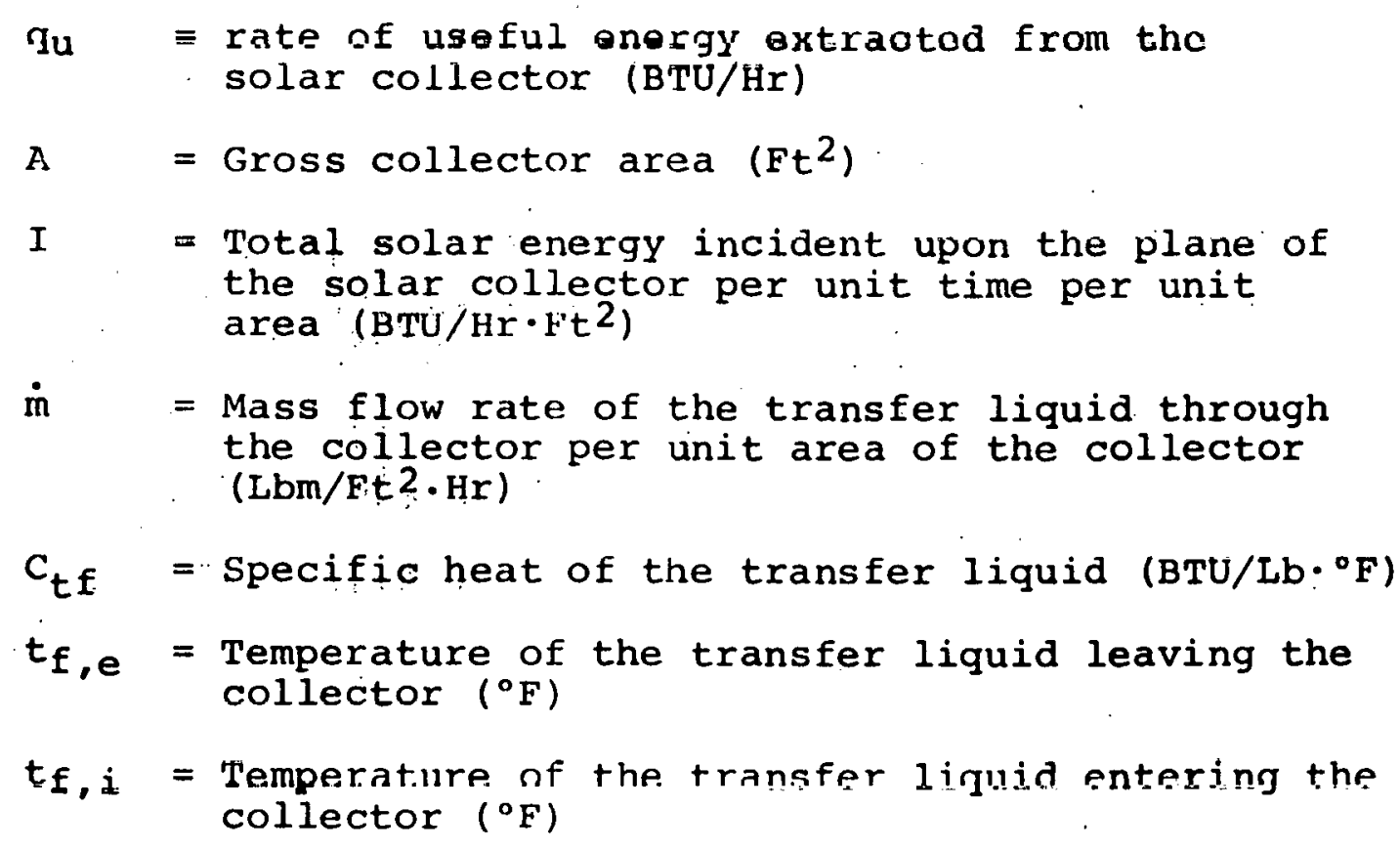

Rewriting Equation (1) in terms of the total collector area yield:

$\eta=\frac{(\dot{m} A) c_{t f}\left(t_{f, e}-t_{f, i}\right)}{(I A)}-\frac{\dot{M} c_{t f}\left(t_{f, e}-t_{f, i}\right)}{P_{i}}$

Notice that:

$P_{i}=I A=$ Total power incident on the collector $\dot{\mathrm{m}} A=\dot{M}=$ Total mass flow rate through the collector

Therefore, $\dot{M} r_{t f}\left(t_{f, e}-t_{f, i}\right)=$ Total power collected by the collector. 
6.1 Thermal Performance Test (Continued)

Substitution in Equation (2) results in:

$n=\frac{\text { Pabs }}{\text { Pinc }}$

where:

Pabs = Total collected power

Pinc $=$ Total incident power

This value of efficiency is expressed as a percentage by multiplying by 100 . This expression for percent efficiency is:

Collector Efficiency $=\frac{\text { Pabs }}{\text { Pinc }} \times 100$

or from Equation (2), collector efficiency is defined by the equation:

\& $\operatorname{Eff}=\frac{\dot{M} c_{t f}\left(t_{f, e}-t_{f, i}\right)}{\text { Pinc }} \times 100$

Each term in Equation (5) was measured and recorded independently during the test. The calculated values of efficiency were determined at sixty-second intervals. The mean value of efficiency was determined over a fiveminute period during which the test conditions remained in a quasi-steady state. Each five-minute period constitutes one "data point" as is graphically depicted on a plot of percent efficiency versus

$$
\left.\left(t_{i}-t_{a}\right) \% I\right)
$$

where:

$t_{i}=$ Liquid inlet temperature $\left({ }^{\circ} \mathrm{F}\right)$

$t_{\mathbf{a}}=$ Ambient temperature $\left({ }^{\circ} \mathrm{F}\right)$

$I=$ Incident flux per unit area (BTU/Hr $\cdot \mathrm{Ft}^{2}$ )

The abscissa term $\left(\left(t_{i}-t_{a}\right) / I\right)$ was used to normalize the effect of operating at slightly different values of I, $t_{i}$ and $t_{a}$. The results are shown graphically in Figures 5 through 11 with the supporting test data given in Tables I through VII. 
6.1 Thermal Performance Test (Continued)

Reference 2.2 uses the following terms relating to the graphical presentation of solar collector thermal efficiency data:

$F_{R} d \tau=$ intercept of the efficiency curve on the ordinate axis

$\mathrm{F}_{\mathrm{R}_{\mathrm{L}}}=$ the negative of the slope of the efficiency curve

$\mathrm{F}_{\mathrm{R}}=$ the solar heat removal factor

$\alpha \quad=$ absorptance of the collector surface for solar radiation

$\tau^{\prime} \quad=$ transmittance of the solar collector cover plate

$\mathrm{U}_{\mathrm{L}} \doteq$ solar collector heat transfer loss coefficient

No cover plate was used in these tests; therefore $\tau=1$. The factors determining $F_{R}$ and $U_{L}$ are basically thermophysical properties - such as thermal conductivity, emissivity and absorptivity - geometry, and flow rate. The interrelations of these factors allow different configurations to perform better at different liquid inlet temperatures.

The selectively coated absorber plate did out perform all others in overall performance. Adding thermal compound did slightly increase FR, but without a compensating decrease in $U_{L}$ the overall efficiency was decreased. Table VIII contains a summary of the overall performance rankings and a comparison of performance at a low inlet temperature and a medium inlet temperature. 
TABLE I

THERMAL PERFORMANCE TEST DATA

FOR ELCAM CONFIGURATION \# 1

\begin{tabular}{|c|c|c|c|c|c|c|c|}
\hline $\begin{array}{l}\text { Solar Flux } \\
\text { BTU/Hr-Ft }\end{array}$ & $\begin{array}{l}\text { Flow } \\
\text { GPM }\end{array}$ & $\left.{ }^{T_{i}} \frac{{ }^{F}}{F}\right)$ & $\begin{array}{l}\text { Tout } \\
\left({ }^{\circ} \mathrm{F}\right)\end{array}$ & $\mathrm{T}_{\text {ambient }}$ & $\mathrm{T}_{\text {out }}{ }^{-\mathrm{T}_{\text {in }}}$ & $\frac{\mathrm{T}_{\mathrm{in}}-\mathrm{T}_{\mathrm{amb}}}{\mathrm{I}}$ & $\begin{array}{l}\text { Efficiency } \\
\text { (Per Cent) }\end{array}$ \\
\hline 303.0 & 0.301 & 88.0 & 93.0 & 73.4 & 5.0 & 0.048 & 72.7 \\
\hline 303.0 & 0.150 & 89.9 & 99.2 & 74.1 & 9.3 & 0.052 & 67.3 \\
\hline 303.0 & 0.297 & 126.9 & 129.3 & 75.8 & 2.4 & 0.168 & 33.8 \\
\hline 303.0 & 0.153 & 125.4 & 130.1 & 75.1 & 4.7 & 0.163 & 34.3 \\
\hline 303.0 & 0.298 & 180.2 & 178.6 & .79 .4 & $-i .6$ & 0.333. & -22.3 \\
\hline 303.0 & 0.148 & 176.1 & 174.0 & 79.7 & -2.1 & 0.318 & -14.5 \\
\hline
\end{tabular}


TABLE II

\section{THERMAL PERFORMANCE TEST DATA \\ FOR ELCAM CONFIGURATION \#2}

\begin{tabular}{|c|c|c|c|c|c|c|c|}
\hline $\begin{array}{l}\text { Solar Flux } \\
\mathrm{BTU} / \mathrm{Hr}-\mathrm{Ft} \mathrm{C}^{2}\end{array}$ & $\begin{array}{l}\text { Flow } \\
\text { GPM }\end{array}$ & $\mathrm{T}_{(\mathrm{i}} \frac{\left.{ }_{\mathrm{F}}\right)}{}$ & $\begin{array}{l}\text { Tout } \\
\left({ }^{\circ} \mathrm{F}\right)\end{array}$ & $\mathrm{T}_{\text {ambient }}$ & $\mathbf{T}_{\text {out }}{ }^{-T_{\text {in }}}$ & $\frac{T_{i n}-T_{a m b}}{I}$ & $\begin{array}{l}\text { Efficiency } \\
\text { (Per Cent) }\end{array}$ \\
\hline 302.3 & 0.302 & 88.4 & 93.7 & 76.2 & 5.3 & 0.0404 & 76.5 \\
\hline 302.3 & 0.151 & 90.5 & 100.6 & 77.2 & 10.1 & 0.0440 & 73.4 \\
\hline 302.3 & 0.297 & 126.7 & 129.0 & 77.6 & 2.3 & 0.1624 & 32.5 \\
\hline 302.3 & 0.151 & 125.2 & 130.3 & 79.3 & 5.1 & 0.1518 & 36.7 \\
\hline 298.5 & 0.294 & 174.5 & 172.5 & 77.9 & -2.0 & 0.3236 & -27.98 \\
\hline 298.5 & 0.151 & 170.6 & 168.5 & 79.1 & -2.1 & 0.3065 & -15.42 \\
\hline
\end{tabular}




\section{TABIEE III}

\section{THERMAL PERFORMANCE TEST DATA}

FOR ELCAM CONI'IGURATION \#3

\begin{tabular}{|c|c|c|c|c|c|c|c|}
\hline $\begin{array}{l}\text { Solar Flux } \\
\text { BTU/Hr-Ft }\end{array}$ & $\begin{array}{l}\text { Flow } \\
\text { GPM }\end{array}$ & $\mathrm{T}_{\left(\frac{i n}{0} \mathrm{~F}\right)}$ & $\begin{array}{l}\text { Tout } \\
\left({ }^{\circ} \mathrm{F}\right)\end{array}$ & $\mathrm{T}_{\text {ambient }}$ & $\mathrm{T}_{\text {out }}-\mathrm{T}_{\text {in }}$ & $\frac{T_{\text {in }}-T_{a m b}}{I}$ & $\begin{array}{l}\text { Efficiency } \\
\text { (Per Cent) }\end{array}$ \\
\hline 298.9 & 0.299 & 87.9 & 93.7 & 80.3 & 5.8 & .025 & 84.97 \\
\hline 298.9 & 0.152 & 91.4 & 101.7 & 82.0 & 10.3 & .031 & 76.30 \\
\hline 298.9 & 0.299 & 129.8 & 133.2 & 83.5 & 3.4 & .154 & 49.00 \\
\hline 298.9 & 0.157 & 128.6 & 135.3 & 83.5 & 6.7 & .150 & 50.63 \\
\hline 298.9 & 0.293 & 185.9 & 186.0 & 84.2 & .1 & .340 & 1.39 \\
\hline $298.9^{\circ}$ & $0 . .146$ & 181.8 & $183: 0$ & 84.6 & $1.2: \ldots$ & .325 & 8.29 \\
\hline
\end{tabular}


'I'ABמA: IV

THERMAL PEKHUIMMNCE 'TEST DATA

FOR ELCAM CONFIGURA'TION \#4

\begin{tabular}{|c|c|c|c|c|c|c|c|}
\hline $\begin{array}{l}\text { Solar Flux } \\
\text { BTU/Hr-Ft }\end{array}$ & $\begin{array}{l}\text { Flów } \\
\text { GPM }\end{array}$ & $\mathrm{T}_{\left(\frac{\mathrm{i}}{\mathrm{F}}\right)}$ & $\begin{array}{l}\text { Tout } \\
\left({ }^{\circ} \mathrm{F}\right)\end{array}$ & $\mathrm{T}_{\text {ambient }}$ & $T_{\text {out }}-T_{\text {in }}$ & $\frac{T_{i_{n}}-T_{a m b}}{I}$ & $\begin{array}{l}\text { Efficiency } \\
\text { (Per Cent) }\end{array}$ \\
\hline 299.7 & 0.302 & 87.7 & 92.2 & 77.0 & 4.5 & .033 & 66.0 \\
\hline 299.7 & 0.151 & 89.0 & 97.1 & 78.6 & 8.1 & .034 & 59.4 \\
\hline 299.7 & 0.302 & 131.5 & 133.2 & 79.9 & 1.7 & .172 & 24.71 \\
\hline 299.7 & 0.153 & 130.0 & .133 .6 & 80.3 & $3: 6$ & .165 & 26.55 \\
\hline 299.7 & $0: 298$ & 181.6 & 179.7 & 82.2 & -.9 & .328 & -12.69 \\
\hline 299.7 & 0.154 & 177.2 & 176.4 & 82.9 & -.8 & .314 & -5.85 \\
\hline
\end{tabular}


TABLE: $V$

THERMAL PERFORMANCE TEST DATA

FOR ELCAM CONIIGURATION \#5.

\begin{tabular}{|c|c|c|c|c|c|c|c|}
\hline $\begin{array}{l}\text { Solar Flux } \\
\text { BTU/Hr-Ft }\end{array}$ & $\begin{array}{l}\text { Flow } \\
\text { GPM }\end{array}$ & $\left.{ }^{\mathrm{T}_{i}}{ }^{\circ} \mathrm{F}\right)$ & $\begin{array}{l}\text { Tout } \\
\left({ }^{\circ} \mathrm{F}\right)\end{array}$ & $\mathrm{T}_{\text {ambient }}$ & $T_{\text {out }}{ }^{-T_{\text {in }}}$ & $\frac{T_{i n}-T_{a m b}}{I}$ & $\begin{array}{l}\text { Efficiency } \\
\text { (Per Cent) }\end{array}$ \\
\hline 299.4 & 0.293 & 88.7 & 94.3 & 83.5 & 5.6 & .017 & 79.75 \\
\hline $299: 4$ & 0.152 & 93.0 & 103.4 & 84.0 & 10.4 & .020 & 76.88 \\
\hline 299.4 & 0.301 & 125.4 & 127.7 & 74.0 & 2.3 & .171 & 33.32 \\
\hline 299.4 & 0.151 & 123.3 & 128.5 & 74.8 & 5.2 & .161 & 37.81 \\
\hline 299.4 & 0.302 & 181.8 & 180.4 & 78.7 & -1.4 & .344 & -20.05 \\
\hline 299.4 & 0.146 & 177.6 & 175.7 & .79 .4 & -1.9 & .327 & $-13 \cdot 10$ \\
\hline
\end{tabular}


TABLE VI

THERMAL PERFORMANCE TEST DATA

FOR ELCAM CONFIGURATION \#6

\begin{tabular}{|c|c|c|c|c|c|c|c|}
\hline $\begin{array}{l}\text { Solar Flux } \\
\text { BTU/Hr-Ft }\end{array}$ & $\begin{array}{l}\text { Flow } \\
\text { GPM }\end{array}$ & $\mathrm{T}_{(\dot{\partial} \boldsymbol{F})}$ & $\begin{array}{l}\text { Tout } \\
(\circ \mathrm{F})\end{array}$ & $\mathrm{T}_{\text {ambient }}$ & $\mathrm{T}_{\text {out }}{ }^{-\mathrm{T}_{\text {in }}}$ & $\frac{\mathrm{T}_{\mathrm{in}}-\mathrm{T}_{\mathrm{amb}}}{\mathrm{I}}$ & $\begin{array}{l}\text { Efficiency } \\
\text { (Per Cent) }\end{array}$ \\
\hline 300.9 & 0.302 & 89.5 & 94.8 & 74.8 & $5 \cdot 3$ & .048 & 77.41 \\
\hline 300.9 & 0.149 & 88.9 & 99.9 & 83.3 & 11.0 & .018 & 79.14 \\
\hline 300.9 & 0.300 & 138.3 & 130.8 & 78.4 & 2.5 & .165 & 35.92 \\
\hline 300.9 & 0.151 & 134.4 & 138.9 & 84.7 & 4.5 & .165 & 32.57 \\
\hline 300.9 & 0.302 & 182.8 & 180.6 & 79.8 & -2.2 & .342 & -31.36 \\
\hline 300.9 & 0.146 & 183.4 & 180.6 & 86.2 & -2.8 & .323 & -19.22 \\
\hline
\end{tabular}


TABIE VII

\section{THERMAL PERFORM $N$ NCE TEST DATA}

FOR ELCAM CONFIGURATION \#7

\begin{tabular}{|c|c|c|c|c|c|c|c|}
\hline $\begin{array}{l}\text { Solar Flux } \\
\text { BTU/Hr-Ft }\end{array}$ & $\begin{array}{l}\text { F low } \\
\text { GPM }\end{array}$ & $\left.\mathrm{T}_{(\dot{\delta}} \frac{n}{F}\right)$ & $\begin{array}{l}\text { Tout } \\
\left({ }^{\circ} \mathrm{F}\right)\end{array}$ & $\mathrm{T}_{\text {ambient }}$ & $\mathrm{T}_{\text {out }}{ }^{-\mathrm{T}_{\text {in }}}$ & $\frac{\mathrm{T}_{\mathrm{in}_{\mathrm{n}}}-\mathrm{T}_{\mathrm{amb}}}{\mathrm{I}}$ & $\begin{array}{l}\text { Efficiency } \\
\text { (Per Cent) }\end{array}$ \\
\hline 300.9 & 0.302 & 88.4 & 92.6 & 83.0 & 4.2 & .017 & 61.34 \\
\hline 300.9 & 0.153 & 89.9 & 97.5 & 83.8 & 7.6 & .020 & 56.32 \\
\hline 300.9 & 0.299 & 132.8 & 134.6 & 84.9 & 1.8 & .159 & 25.76 \\
\hline 300.9 & 0.152 & 131.8 & 135.1 & 85.4 & 3.8 & .152 & 26.90 \\
\hline 300.9 & 0.299 & 189.0 & 187.5 & 86.3 & -1.5 & .341 & $-21 \cdot 14$ \\
\hline 300.9 & 0.154 & 184.9 & 183.3 & 86.5 & -1.6 & .327 & -11.66 \\
\hline
\end{tabular}


RANKING OF THE SEYEN ELCAM CONFIGURATIONS BASED ON OVERALI PERFORMANCE

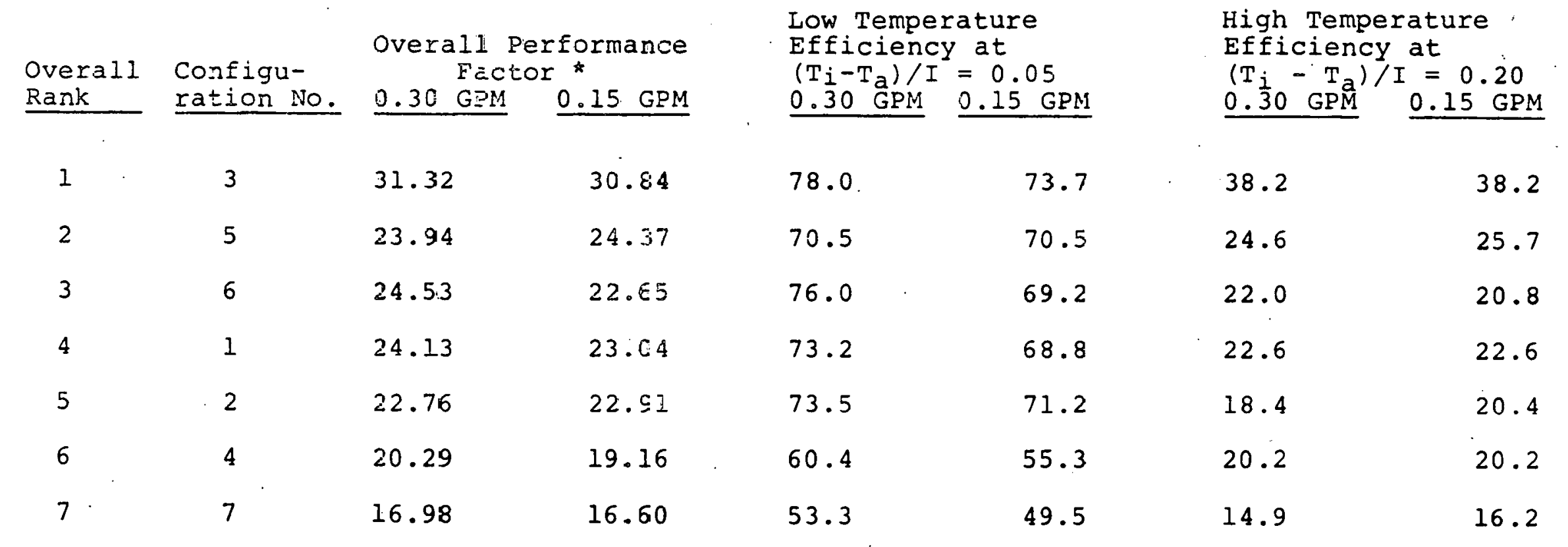

* Overall performance factor is the value of $\eta\left(\frac{T_{i}-T_{a}}{I}\right)$ integrated over the range of $\eta=$ Max. to $\eta=0$. This factor applicable for comparison purposes for this test only. 


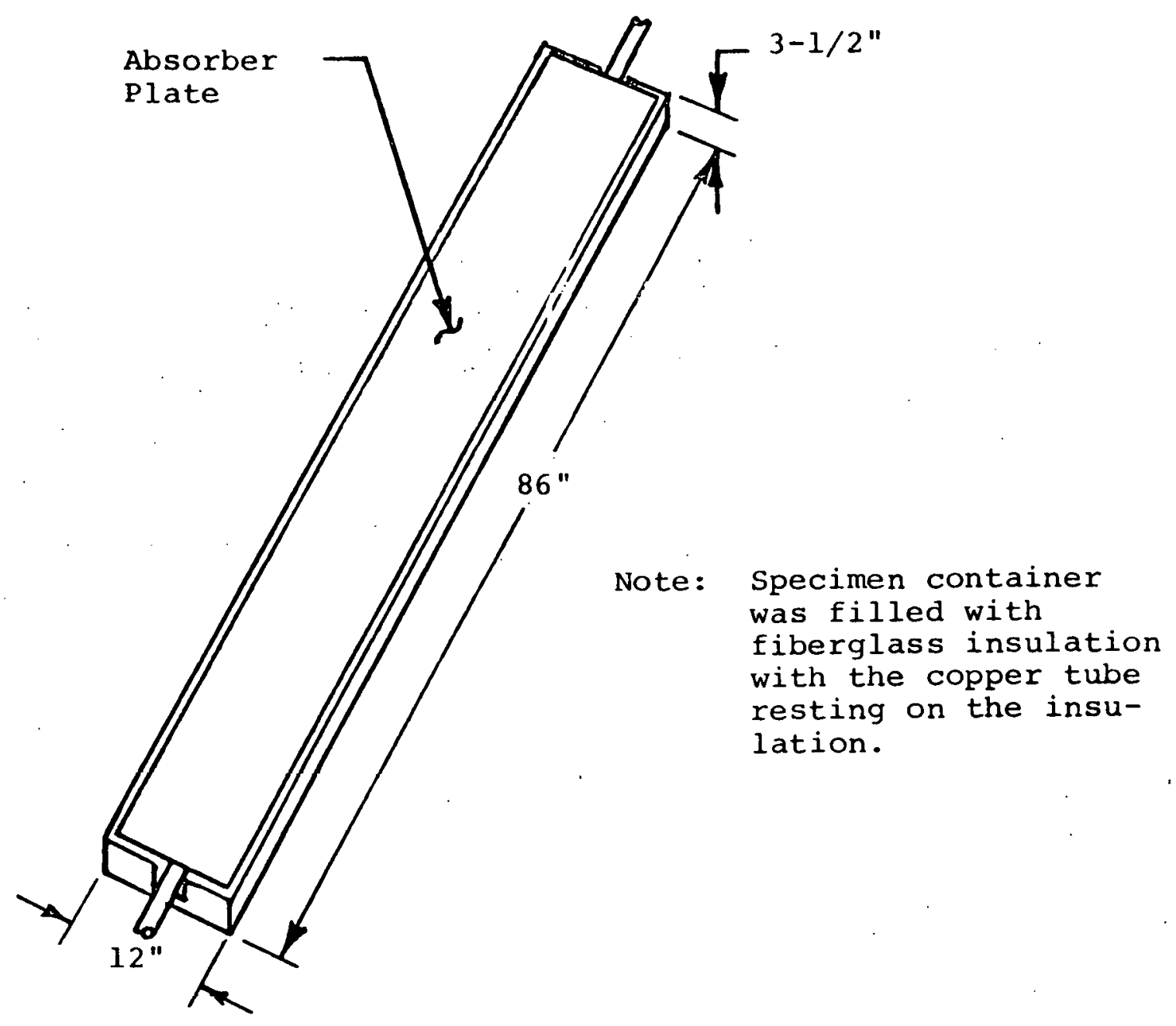

Figure 1. Schematic of Test Specimen and Supporting Apparatus 


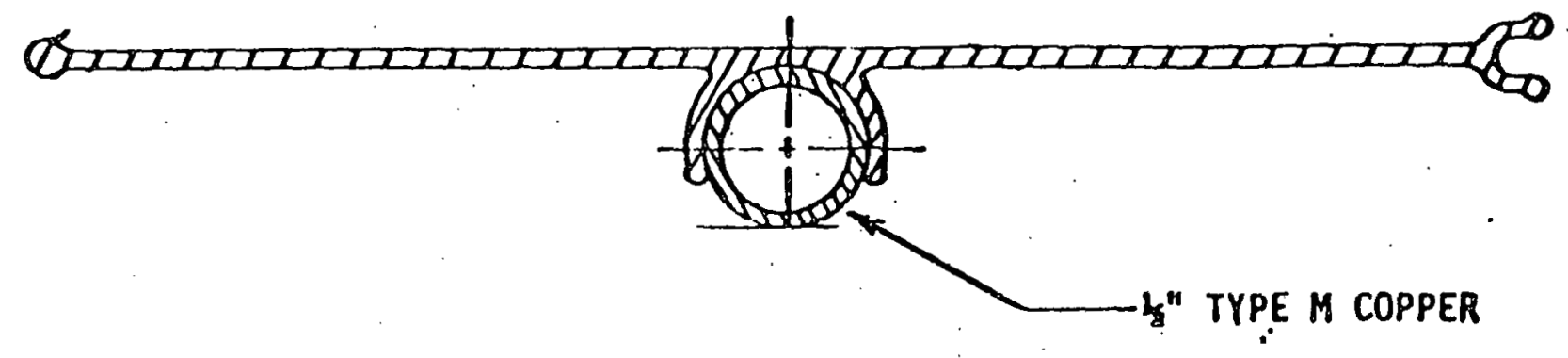

Figure 2. Basic Design for Elcam Configurations \#1, \#2, \#3, and \#6 


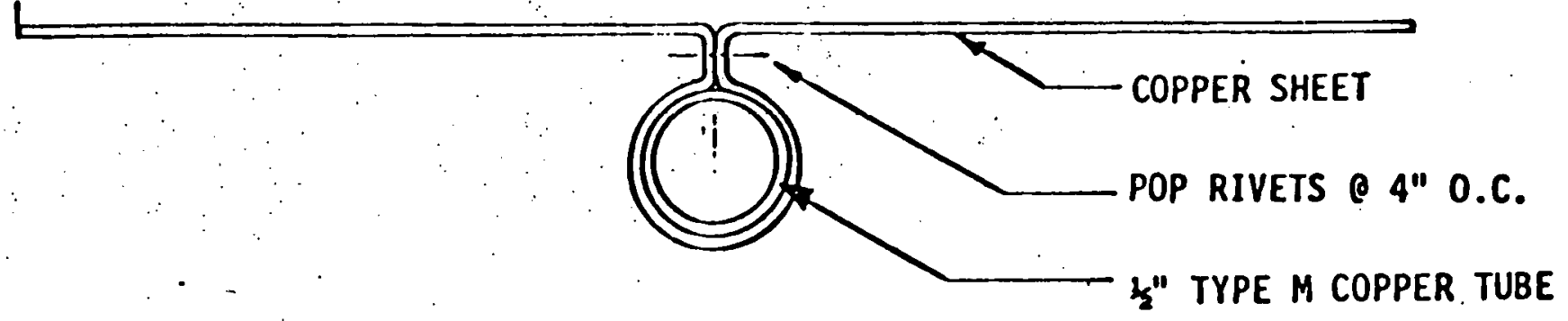

Figure 3. Basic Design for Elcam Configurations \#4 and \#7 


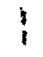

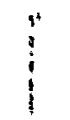

$i^{\circ}$

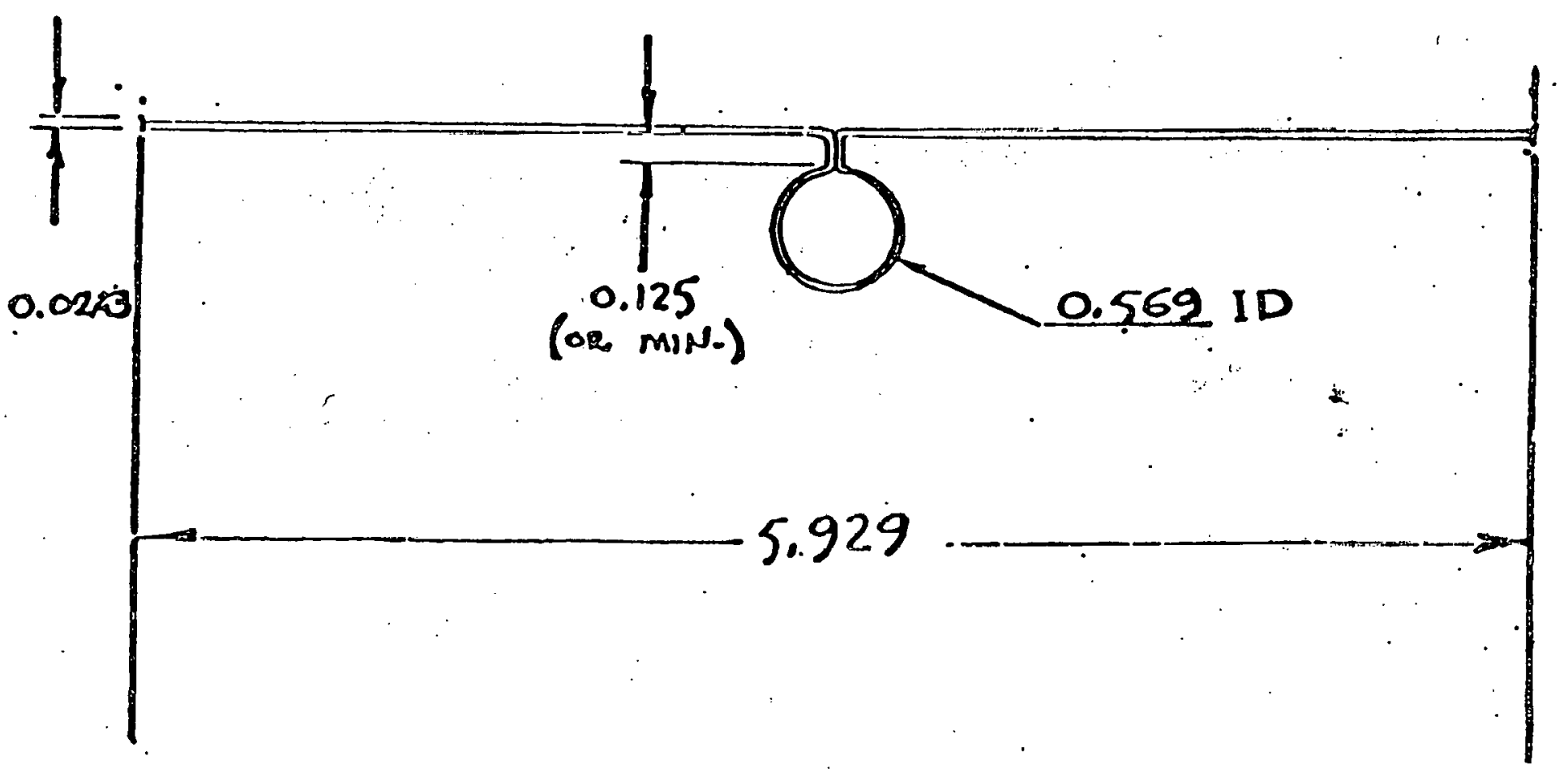

NOTE: SEAM JOINTS TO BE CONTINUOUSLY BRAZED

Figure 4. Basic Design for Elcam Configuration \$5

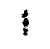




\section{( 1 NoE}

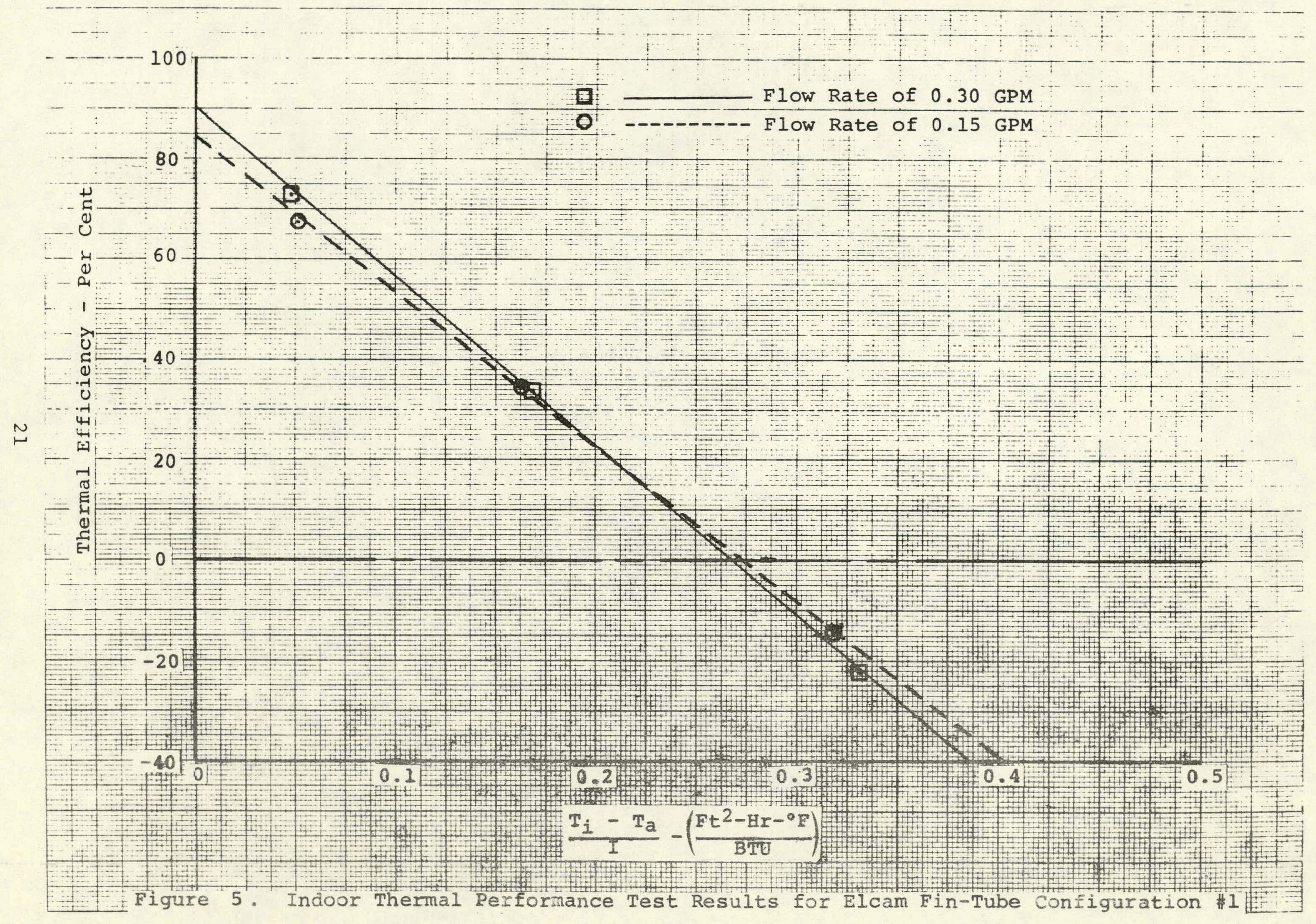




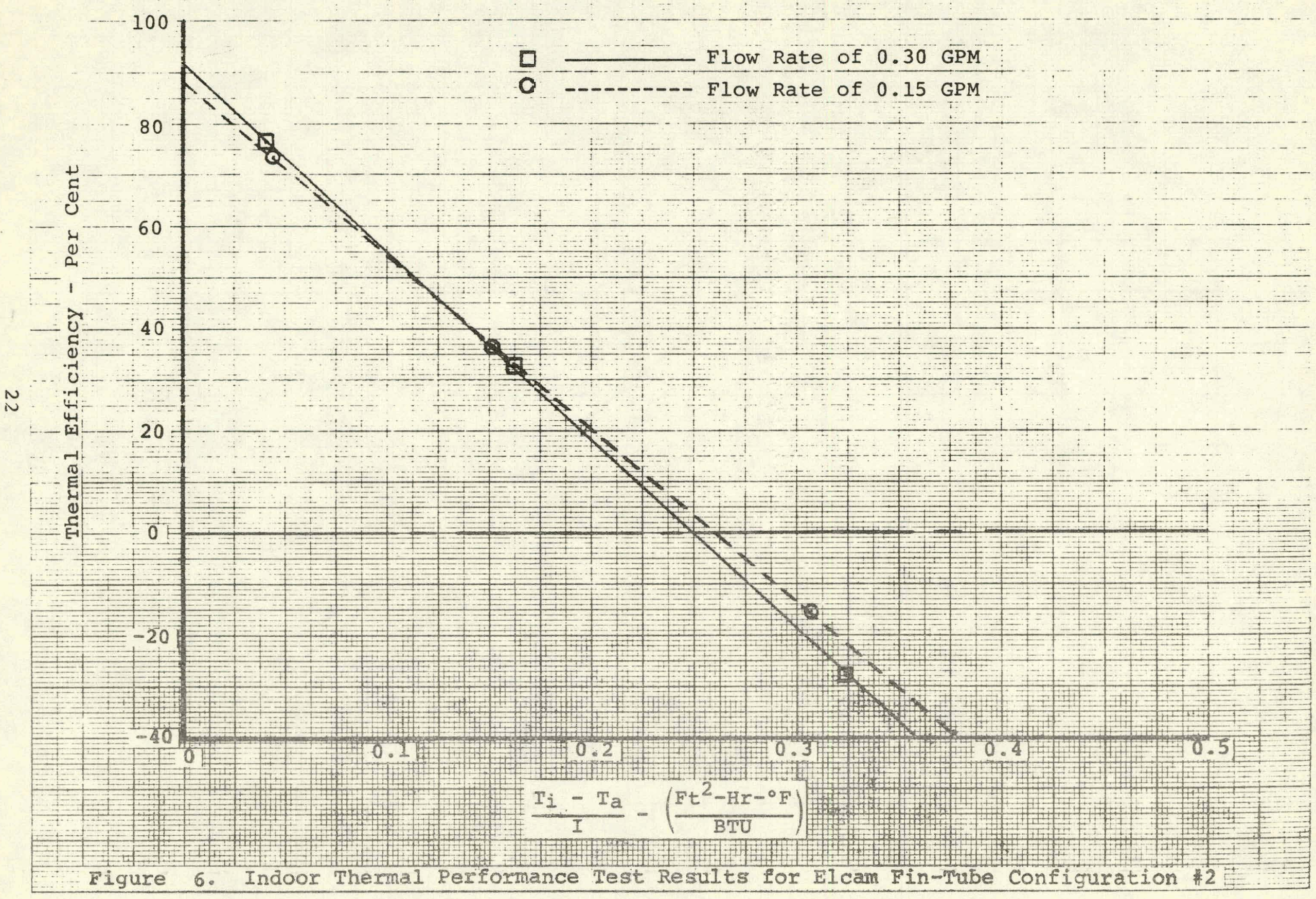




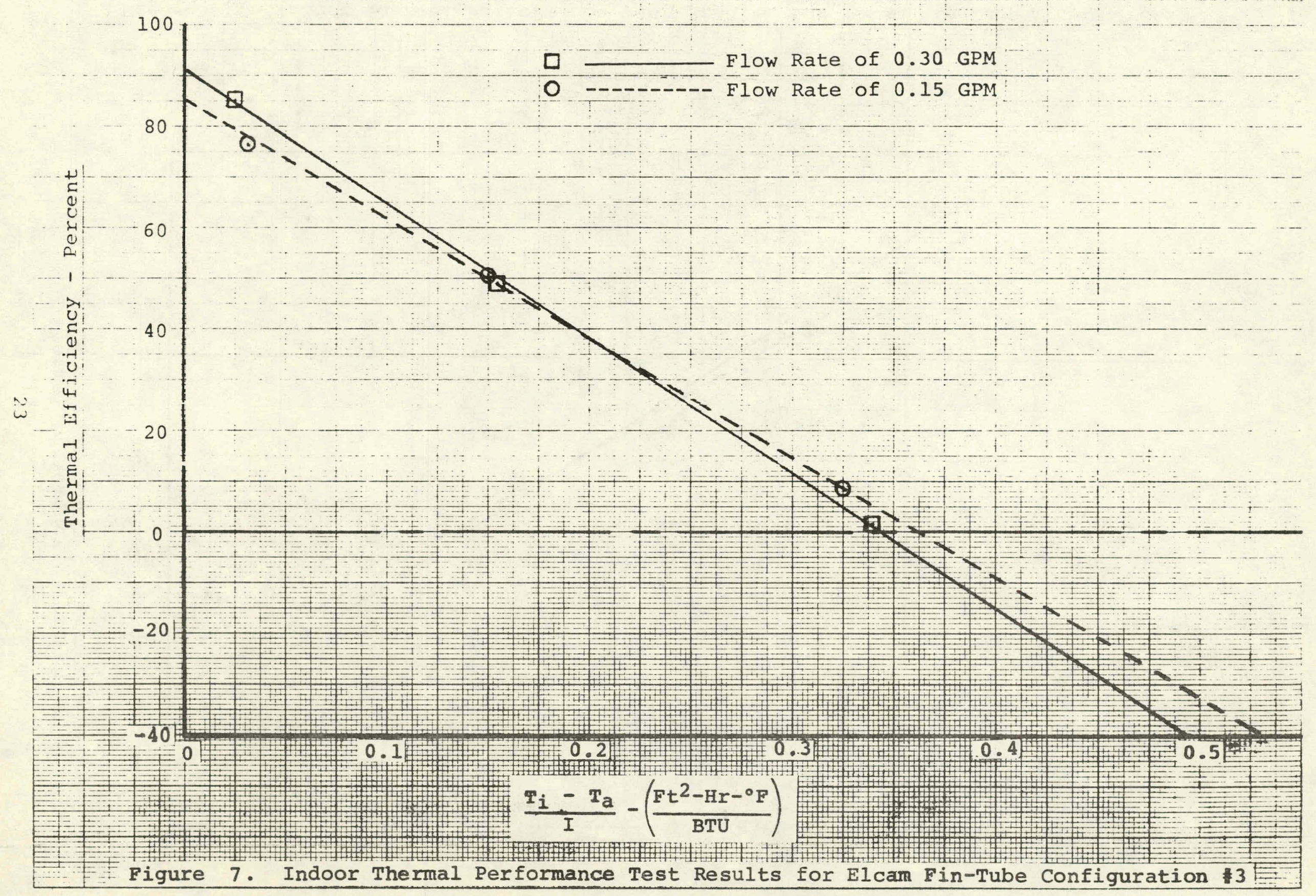




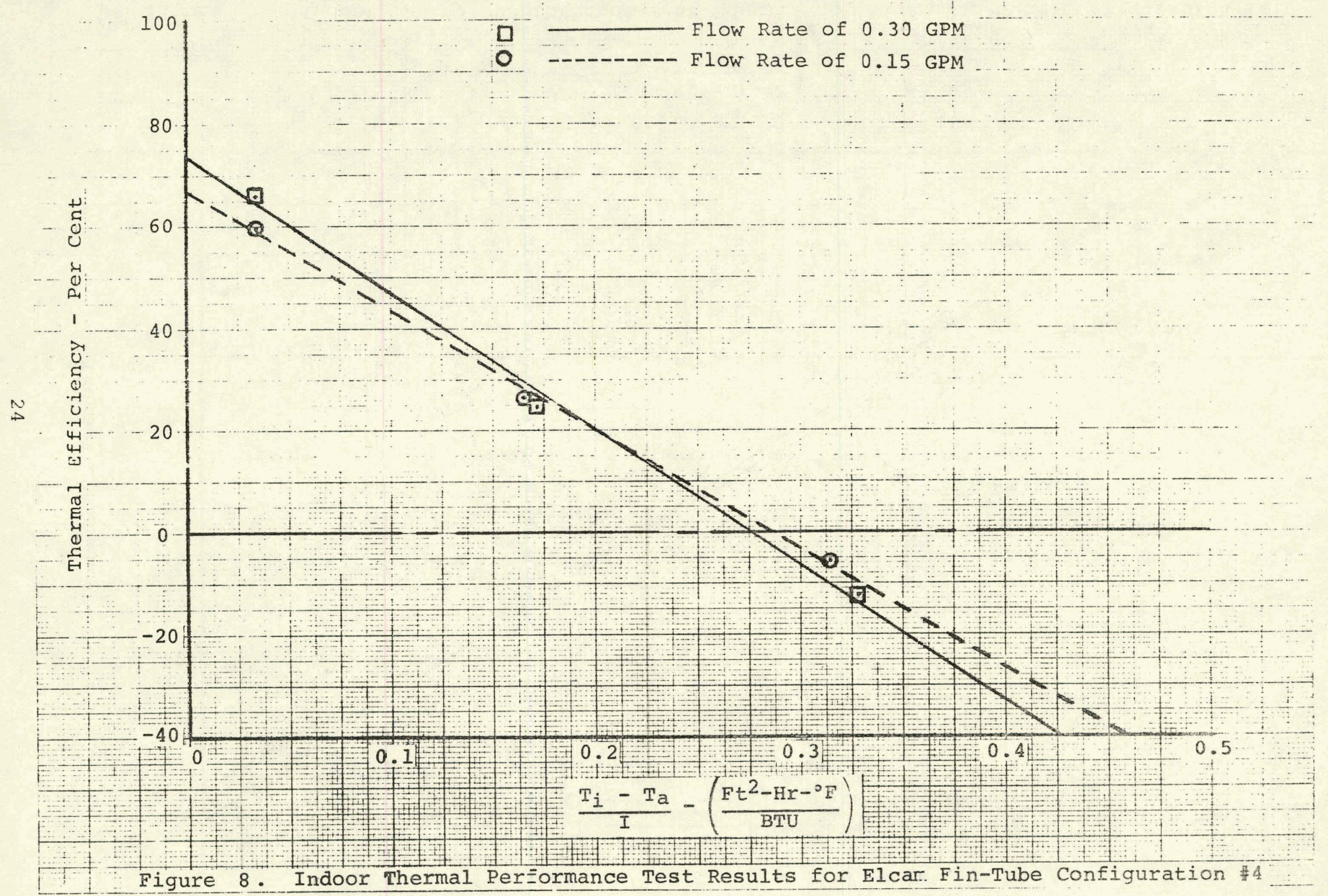




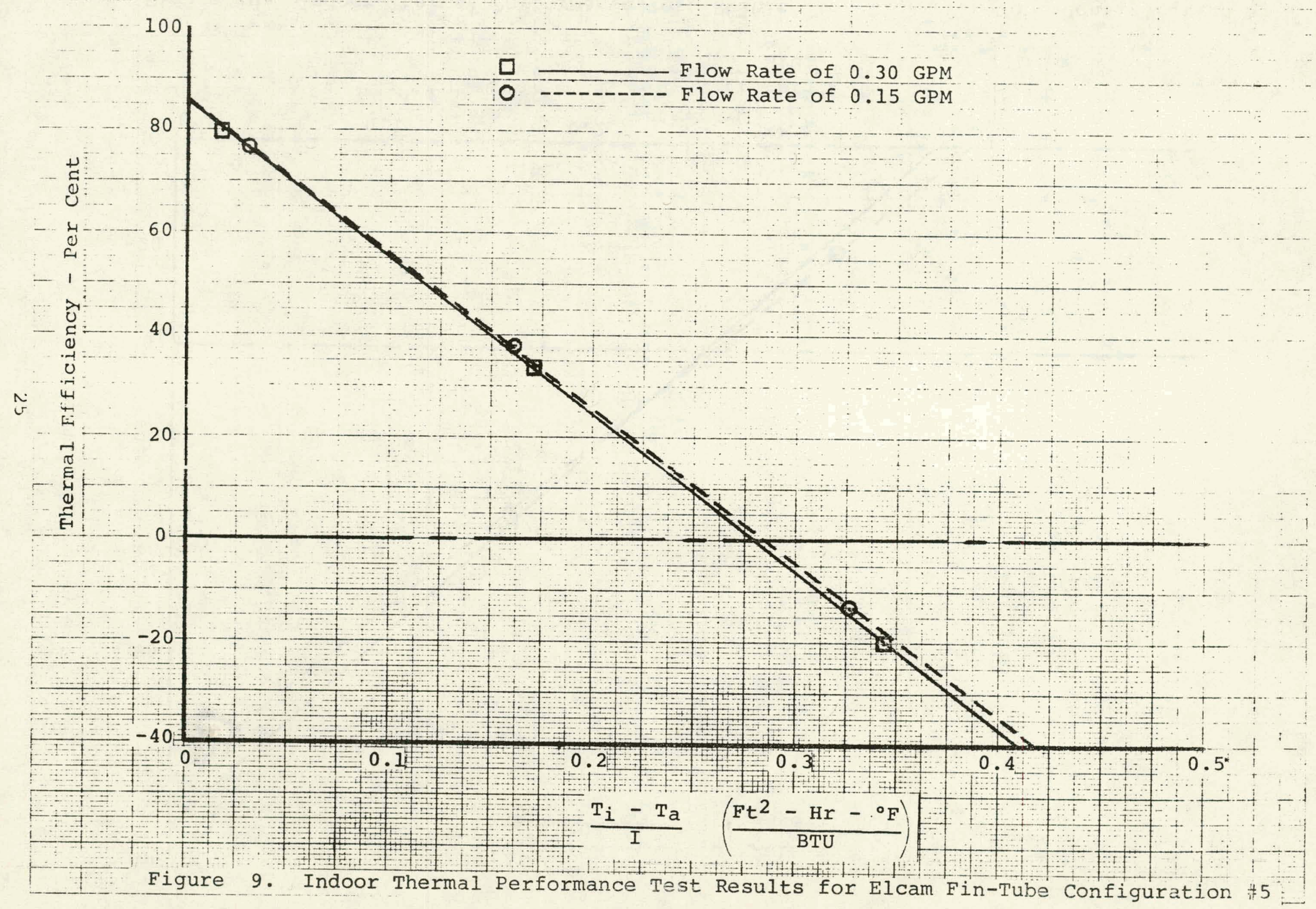




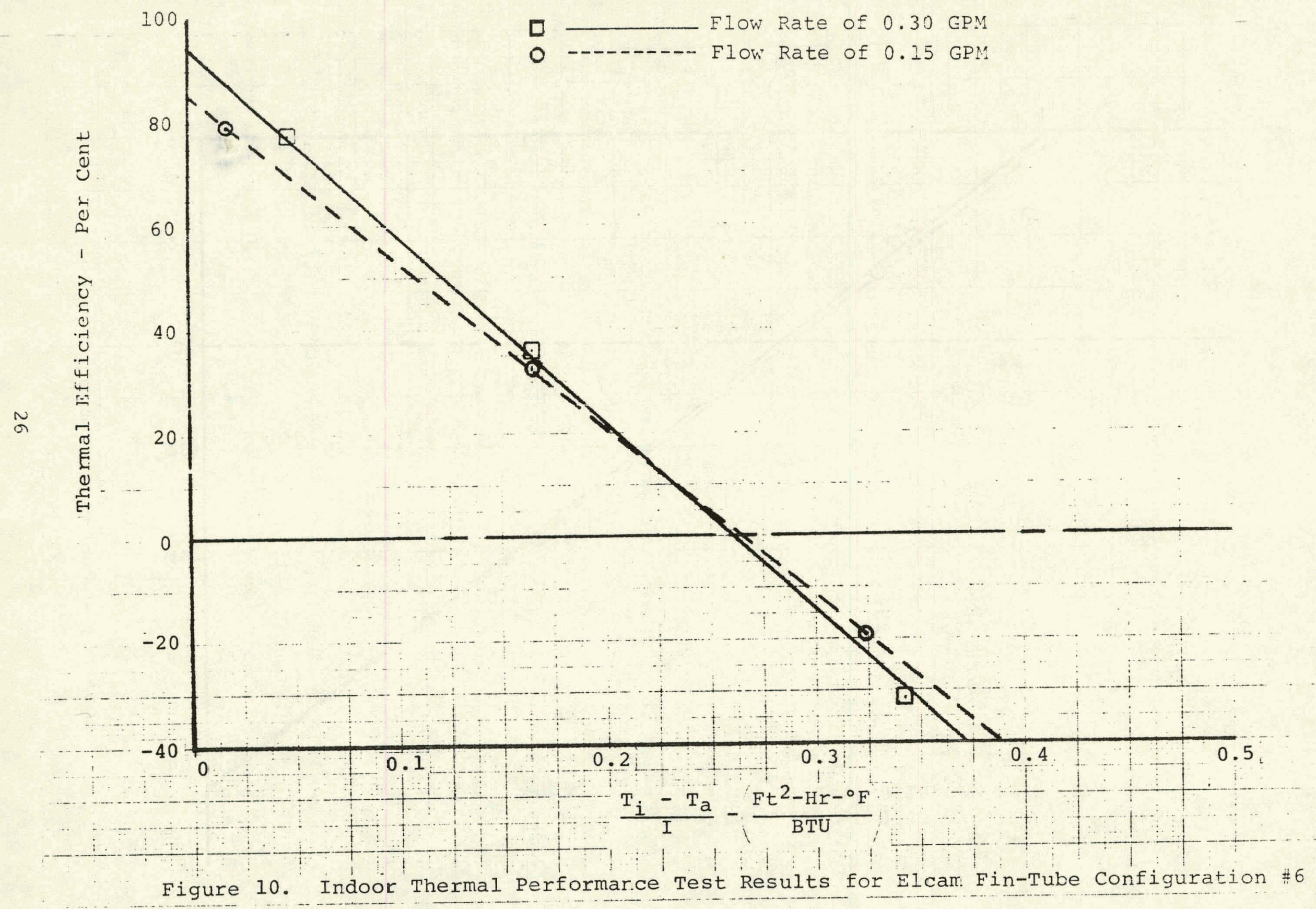




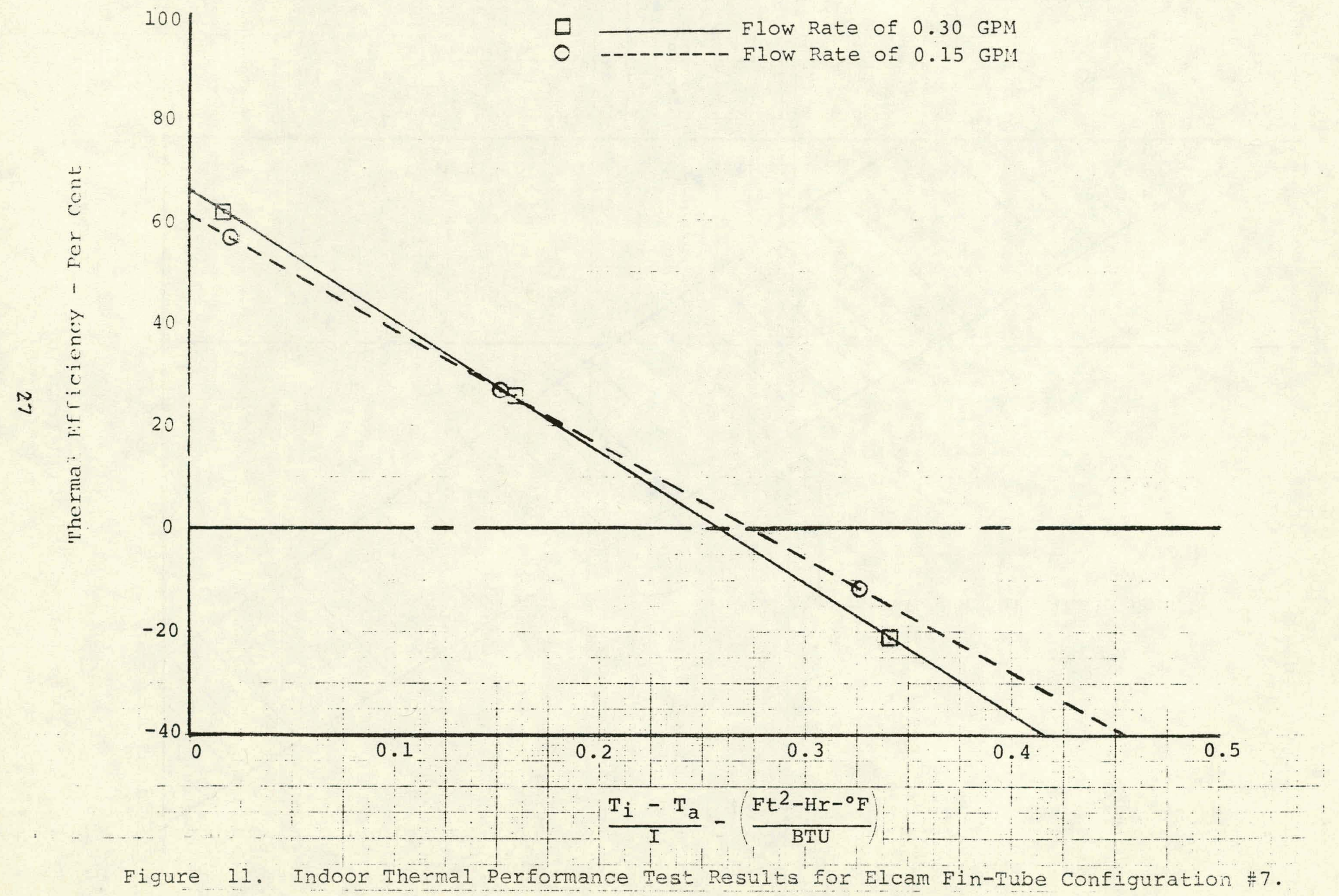




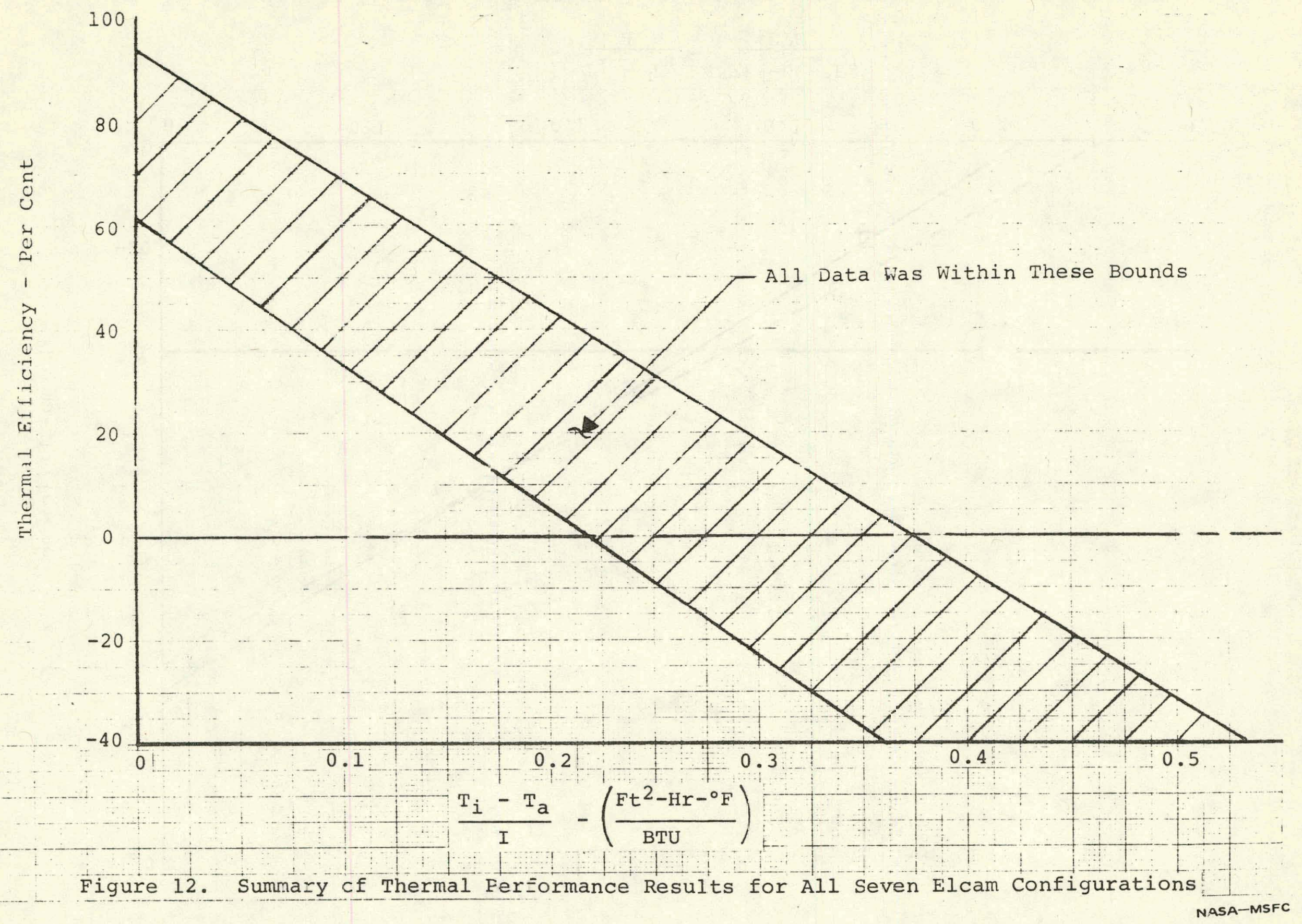

